\section{Getting Heard: The CRASH Project, A Case Study of Community Involvement with "At Risk" Secondary School Students}

\section{Lloyd Martin, KeITH SUlLIVAN AND MARCia NorTON}

\section{Abstract:}

The CRASH (Cultural, Recreational, Academic, Skills for life, and Health) programme was designed for "at risk" secondary students and ran for the 1996 and 1997 school years in a multi-ethnic Porirua secondary school. The research which accompanied the project derives its strength from the triangulation of the experiences and perceptions of the teachers, the CRASH course tutors (local community youthworkers) and the students. The research has developed theoretical and practical understandings of the achievements and shortcomings of the project. This particular article provides an overview of the CRASH programme and focuses specifically on the students' perspective. CRASH was found to be a positive experience for the students who participated, at least in the short term. A central feature of the programme's success was the ability of successful tutors both to create a safe place for "at risk" students and to assist them in "getting heard".

$\mathrm{T}$

he terms "delinquent", "troubled youth", "at risk" and "street kid" and, more recently, "multiple problem" and "behaviourally disturbed" have all been used to describe youth who are in some way marginalised from mainstream society. In discussions prior to setting up the project which forms the subject of this article, Martin and a group of fellow youthworkers developed a model (see Figure 1) which was refined in the writing of the paper, and which suggests that young people live their lives in four major interacting social environments the family, the peer group, the ethnogeographic community and the school.

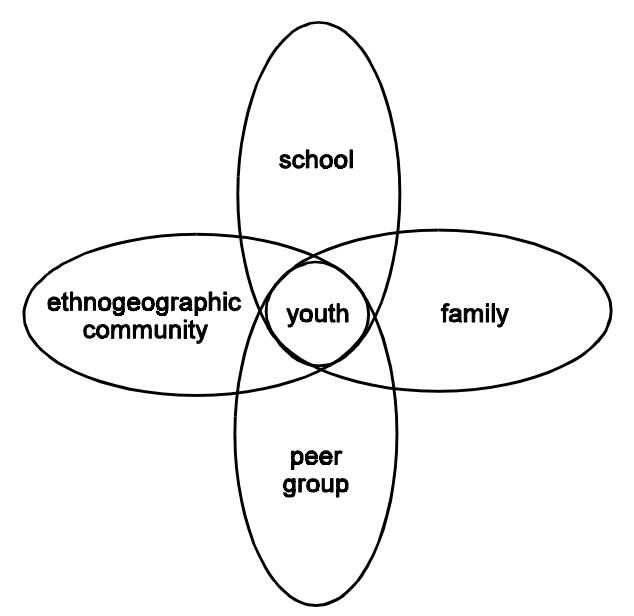

Figure 1 Four key social environments of a young person

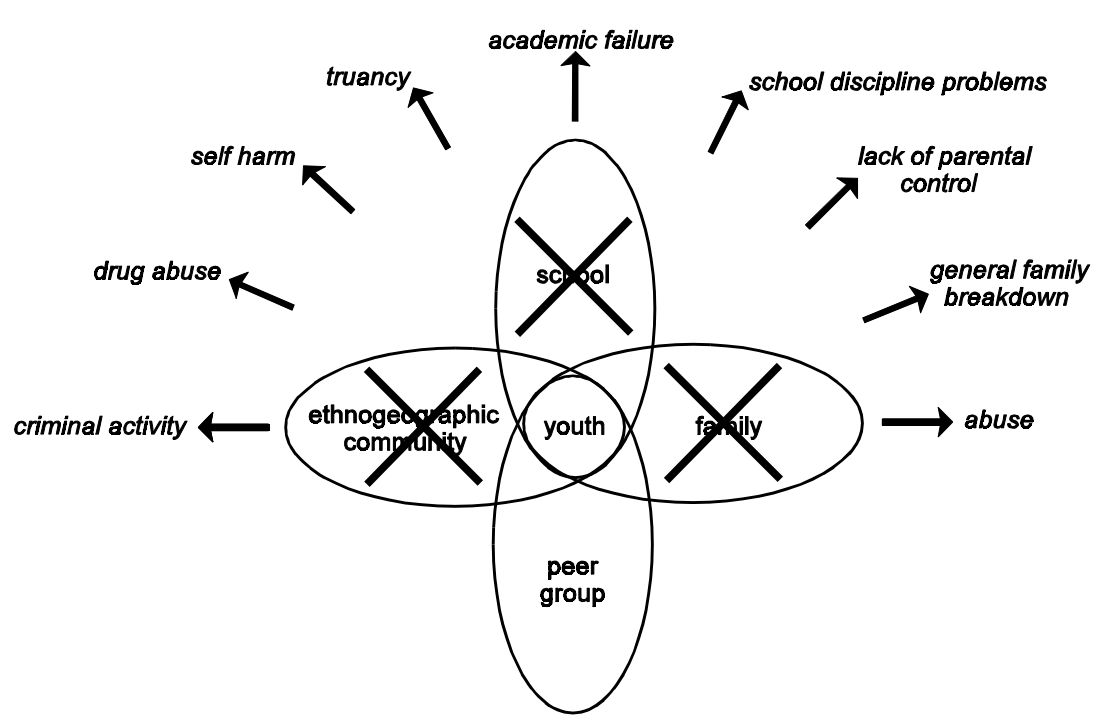

Figure 2 The breaking down of the social environments 
When one or more factors in a young person's social environment breaks down, that young person could be described as being at risk. The second diagram (Figure 2) illustrates the influences that contribute to such a breakdown. An indication of the level of risk under which a young person is operating is related to the extent of the collapse in each environment. At school this might involve academic failure and ongoing discipline issues. At home it may mean family breakdown due, for instance, to lack of parental control, or abuse. Any community has both cultural (ethnic) and geographical characteristics, and young people from minority culture backgrounds relate to both environments. A breakdown can occur in either or both. In the context of the geographical community, it may mean involvement with the law. In an ethnic community, breakdown can occur when a young person, or a whole family, becomes marginalised from that community.

One significant result of whole or partial breakdown in the other three social environments for an "at risk" young person is the creation of a high level of dependency on the peer group for moral and personal decision-making. The youthworkers who were involved in discussions that led to the development of this model concluded that one effect of (or goal for) their intervention was to introduce alternative reference points.

Estimates about the size of this group as a proportion of the secondary school population vary widely. ${ }^{1}$ For instance, Fergusson, Lynskey and Horwood's (1994) fifteen-year longitudinal study in Christchurch suggests this group accounts for 3 percent of their total sample, but the New Zealand-wide study by Denny et al. (1993) reports a much larger 18 percent. Denny et al. note that in terms of gender comparisons, overall "at risk" rates are similar, although different criteria are used. Girls are more likely to be at risk due to abuse, and boys either because of misbehaviour at school or offending. However, if we take the more conservative 3 percent figure of the Christchurch study as being accurate, this would mean (going by the 1995 figures at least) that some 6,500 students in New Zealand are seriously "at risk".

\section{The CRASH Project}

The CRASH project (meaning Cultural, Recreational, Academic, Skills for life, and Health) was funded by a one-off Ministry of Education grant to schools for the development of programmes for "at risk" students, and was coordinated by Lloyd Martin. In this case, it was used in a Porirua secondary school with a large percentage of Maori and
Pacific Nations students. The school in question has suffered from "white flight", as described in the first Smithfield Study report (Lauder et al., 1994). Since the removal of zoning, Pakeha parents have tended to move their children to other schools where they feel their opportunities will be greater. Totara School (a pseudonym) therefore has a significant number of low-SES students, and large Maori and Pacific Nations populations. Funding for the research which accompanied the implementation was provided by the Ministry of Youth Affairs and the Crime Prevention Unit. ${ }^{2}$

The CRASH programme was put in place at the beginning of the 1996 school year and ran for 2 years. The intention of the programme was to create for part of one school day and within the school programme an alternative environment for "at risk", largely ethnic minority, students where these students, supported by tutors from their own communities, could experience some sense of purpose or even success. The research findings elicited fascinating and useful information in relation to the varied experiences and perspectives of the teachers, the youthworkers and the "at risk" students. Taken together, these three complementary perspectives provide an interesting and useful triangulation for developing effective programmes for "at risk" students. The dual purposes of this particular article are to provide a description of the overall programme and to describe in detail one of the perspectives, that of the "at risk" students. ${ }^{3}$

\section{Establishing and Administering the CRASH Programme}

In order to ensure the success of the CRASH programme, it was essential to obtain the support of the school and to involve the community youthworkers, as well as to find an effective way to identify and target the "at risk" students in order to implement the programme.

\section{i. Involving the community}

Fifteen agencies fitting the criteria of community involvement were approached about participating in the CRASH programme. Participation criteria included: a) being located in the Porirua region; b) employing Maori and Pacific Nations youthworkers; and c) being regarded as "safe" by the liaison worker and the guidance counsellor of the school. The community groups responded very positively. Initially, 11 people from 6 agencies agreed to take part and by the end of the first year of operation, this had expanded to 16 people from 10 agencies. 


\section{ii. Identifying "at risk" behaviour}

Peters and Marshall (1989) recommend the use of a school-based diagnostic and assessment technique for identifying and recording the progress of "at risk" students. Such initiatives coming from the school are important in that they can create both a sense of ownership and a willingness to support such a scheme. A group of teachers from the case

Table 1 The three levels of risk and the "at risk" indicators

\begin{tabular}{ll}
\hline LEVEL & INDICATORS OF RISK \\
\hline 1 & Unmotivated, not involved in the learning process \\
& Disorganised/unprepared for class \\
Not involved in school sports or cultural activities \\
Rarely completes homework \\
Late to school at least once a week \\
Two detentions in the last month \\
\hline Ongoing uniform issues \\
Enrolment from another school (after start of year) \\
Single period unexplained absences \\
Regularly late to class \\
On whanau head's reporting sheet (must sign in for each \\
class) \\
Disruptive of other students in class \\
Mixes with an "at risk" peer group \\
Two detentions in the last fortnight \\
A college detention in the last term \\
Returning from Activity Centre \\
Abusive behaviour towards other students \\
Violence towards other students \\
Multi-period unexplained absences \\
Defiance of teacher direction \\
Abusive language/actions towards staff \\
Suspension in the last year \\
Referral from another school (having been suspended) \\
Drinking/drugs at school \\
Evidence of self harm
\end{tabular}

study school developed a list of commonly found characteristics (indicators) of the behaviour of their "at risk" students in the context of the school. This was used to provide the basis for three "at risk" classifications (levels), with level 3 being of highest risk (Table 1).

Form teachers were asked to complete a profile for all students in their class. ${ }^{4}$ Each profile was then checked by the form dean and the guidance counsellor, who added ticks and comments where appropriate. Students with three or more ticks spread across various levels were placed in the level where their median tick occurred. Early in the 1996 school year, a profile was completed for all (327) 3rd, 4th and 5th form students in the school, with 24 percent (79) being identified as at risk. ${ }^{5}$ This exercise was repeated for 3rd form (year 9) students at the end of Term 1, 1997. Table 2 provides information about the movements of the "at risk" students during 1996 and 1997.

Table 2 A breakdown of the movements of "at risk" students

\begin{tabular}{llll}
\hline & LEVEL 1 & LEVEL 2 & LEVEL 3 \\
\hline $\begin{array}{l}\text { Originally identified in profile } \\
(1 / 4 / 96) \text { (\% of all 3rd-5th formers) }\end{array}$ & $32(10 \%)$ & $25(8 \%)$ & $22(7 \%)$ \\
$\begin{array}{l}\text { Have been added to the list } \\
\text { over the year }\end{array}$ & 10 & 10 & 27 \\
$\begin{array}{l}\text { Have left college by end of 1996 } \\
\text { (\% of original students in this level) }\end{array}$ & $3(9 \%)$ & $9(36 \%)$ & $18(82 \%)$ \\
$\begin{array}{l}\text { Totals at 1/12/96. The total of these } \\
\text { figures (96 of 312 ) represents an } \\
\text { increase to 31\% (approx.) of all }\end{array}$ & $39(13 \%)$ & $26(8 \%)$ & $31(10 \%)$ \\
$3-5$ th form students & & & \\
$\begin{array}{l}\text { Have left college by the end of } \\
\text { 1997 (\% out of total number } \\
\text { identified at this level at the end } \\
\text { of 1996) }\end{array}$ & $8(20 \%)$ & $17(49 \%)$ & $21(68 \%)$ \\
$\begin{array}{l}\text { Added to the list (from a profile of } \\
\text { 3rd formers and new enrolments } \\
\text { in May 1997) }\end{array}$ & 6 & 19 & 16 \\
\hline
\end{tabular}


A list for each level was maintained and reviewed three times each year by the guidance counsellor. Students who had left the school were taken off the list and new students were added. The majority who left school were at level 3 (see Table 2). Many of the students who arrived from other schools in the interim exhibited behaviours at the higher levels (levels 2 and 3 ) of the Indicators of Risk list. This usually meant that the student concerned had been suspended, and this was the parents" "next choice" of school. Further, internal movement among Indicators of Risk levels tended to be towards level 3 (6 students were moved from levels 1 and 2 to level 3 during 1996). ${ }^{7}$

\section{iii. Forming groups}

Student referrals to CRASH were made in the first year of the programme by the guidance counsellor and in the second year by the school guidance network (the deans, guidance counsellor and deputy principal). Courses were run by a community tutor and generally consisted of five to seven students. An ongoing dilemma in grouping the students was the need to avoid creating situations that would draw students who were on the fringes of trouble further into friendships with an "at risk" peer group. On the other hand, helping "at risk" students develop friendships with peers deemed to be not "at risk" was seen by teachers as a worthwhile goal. In some cases one or two students who did not qualify as "at risk" (but who staff felt were deserving of some extra support) were added to groups in order to act as a positive influence on the group dynamic.

As the courses within the programme became more popular (by the start of the second year), the coordinator and the guidance counsellor were regularly approached by students individually and in groups to go on courses. Where these approaches were made by students from the "at risk" profile (one or two of whom may have already done a course), a deal was sometimes able to be struck where the student promised good behaviour (e.g., attending school) in return for going on a course. This was seen as an ideal situation, as it avoided mixing levels of students but involved a peer group making a concerted effort to "earn" a course. Any situation where there was a possibility of harnessing peer support to improve performance at school was regarded as an opportunity that should be used.

\section{iv. The content and organisation of the courses}

The courses were usually focused on a common cluster of issues, such as finding reasons to come to school, interpersonal communication skills, dealing with anger/frustration appropriately, and self esteem. The students were also grouped by gender and age (with a group tending to consist of 3 rd and 4 th, or 4 th and 5 th, or just 5 th form students) and with groups having same-gender tutors.

The CRASH courses generally ran for 6 weeks, and tutors tended to develop a balance between activities, visits (e.g., to work places) and group discussions. Some early groups stayed at the school, but most tutors preferred to work off-site, either at their agency's building, or in another community space. Some tutors commented that being off-site in a location other than a classroom improved the group dynamic and allowed them to come across as youthworkers rather than teachers. Groups met once a week for either one or two periods and in some cases they went on an outdoor day activity, such as rafting, for a full day.

If students were going to opt out of a course, they generally did so in the first week or two, and by the 3rd or 4th week attendance had usually settled down. In most courses, one or two students lost interest and dropped out. This had usually been anticipated by making the initial group a little larger than optimal.

\section{v. Getting the programme underway: The initial meeting}

Once it was decided to run a group, a tutor was organised and an initial meeting between the students and the tutor was arranged. At this meeting, someone from the students' group inevitably asked why they had been referred onto the programme ("was it because we were bad?"). Students were told that it was because teachers had felt that their performance at school would benefit from the extra encouragement of being selected to do a course. At this meeting, students were given the opportunity to opt in or out of the course. If they opted in, they were required to bring back a signed consent form from their parents.

\section{vi. A further development: CRASH contracts}

Early feedback from teaching staff and the guidance counsellor suggested that although students were enjoying the CRASH courses, this was not necessarily translating into changed behaviours at school in the areas that were of most concern to teachers (attendance, behaviour in class, completing homework, etc.). After some 
experimentation at the end of the first year, a number of students were selected at the end of each block of courses to continue on with a series of weekly individual interviews (contracts) involving personal goalsetting for an initial period of a further six weeks. The interview process was carried out by the project coordinator, selected youthworkers and a small team of four people employed for this purpose. Encouraging students to set their own goals was central to this process. Frequently, interviewers used questioning as a way of assisting students to clarify the areas they wished to work on.

A number of incentives were built into the contract system. For each goal completed, a student earned an agreed number of "credits". These could be used to earn a place on an outdoors trip or as currency to bid at an auction of small items which was generally held once a term. Students reported being motivated for different reasons. These were:

- the auction;

- the opportunity to work towards "getting out of school on a trip";

- the sense that they were consciously making progress at school;

- having someone to talk to on a regular basis;

- bringing up personal issues in the interview session.

Generally, student-proposed goals were accepted, and interviewers could allocate from 1 to 3 "credits" per goal. Therefore, a goal such as "remembering to bring boots to rugby training" may have been worth one credit (once achieved), and coming to classes or completing homework may have been worth more. It was felt important to keep a cluster of "rewards" in the programme in the hope of motivating a wider cross-section of the students with at least some of them.

Early in the process, it became apparent that goals needed to be both very specific and manageable. Once students were familiar with the process, they were usually able to come up with realistic goals. This straightforward behaviourist approach seemed to work well in this setting.

The addition of the contract approach as a follow up appeared to be a key to translating attitudinal gains made in the CRASH courses into school-based behaviours. Because of successes in the first year, at the start of the second year staff referred a group of students directly onto the contracts to try to give them a positive start to the year. At the suggestion of the guidance counsellor, a number of students who were obviously benefiting from the structure that the contracts provided were left on them through to the end of the project (or until they left school) instead of for the six weeks originally intended.

Interviews were usually carried out on a Monday, and most interviewers were able to complete between two and four contract sessions (interviews) in an hour. A teacher's aid was employed for an hour on Fridays to take the contract sheets and check progress in the areas in which goals had been set with the teachers concerned. This involved checking attendance, behaviour in class, or work completed with the teachers. Issues of confidentiality arose, so the teacher's aid generally checked with teachers verbally rather than showing them the contract sheet.Teacher comments were entered onto the contract sheet by the teacher's aid. Tutors began their "contract sessions" by debriefing the goals from the previous week, based both on written comments from teachers and the student's own perceptions.

\section{The Research}

There are several reasons to carry out research when developing a scheme such as the CRASH programme. Research can provide a record of events; it can give an indication of the extent of its success or failure to meet its intended outcomes; it can provide information upon which to reflect and develop theoretical understandings; it can publicly acknowledge and explain successes and failures; and it can make concrete suggestions for improvement.

In terms of a methodological approach, the research could be described as an action-based case study, and Elliott's (1991, p. 88) idea of "telling the story as it unfolded" was central to both the project and the research. In letting the story unfold from the experiences of the participants it also contains elements of grounded theory. For this research, information was gathered from students as they finished the course in the following three ways:

I. Each person answered a questionnaire designed to answer the question, "What has changed as a result of your participation in CRASH?"

II. Each group was given a set of cards, each of which identified possible characteristics of an effective tutor and was designed to answer the question, "What was most important about your tutor?" Groups (either as a whole, or in clusters of two or three students) were asked to rank the cards in order of importance, using consensus decision-making. This 
could be described as a decision-making focus group process. The process of group decision-making was also useful in enabling the researcher to monitor the discussion that led to their making particular choices.

III. Students were then interviewed individually with interviews focusing on three questions that had emerged over the course of the project as important. These were:

i. Did you feel that the project made any difference for you?

ii. What did you think of your tutor?

iii. How could the project have been run more successfully?

As well as answering these questions, there was implied in the students' answers a question that was not asked, but if it had been formulated would be expressed as:

iv. How did the teachers react to your participation in CRASH?

\section{Results}

Part I: "What has changed as a result of your participation in CRASH?"

The results of this section come from 47 questionnaires filled in by students who had either completed a CRASH course or six to eight sessions of weekly contract meetings with a community tutor. They were asked to fill in a questionnaire identifying areas of change in personal behaviour or circumstances at school since their involvement in the programme. This took the form of a 16-item tick sheet. Students were asked to decide for each item whether, since the course, things had become:

\section{heaps better, better, about the same, worse, heaps worse}

The questionnaires were collated and the responses collapsed into the three categories of positive change (heaps better and better), no change (about the same) and change for the worse (worse and heaps worse). Using the data collected, Tables 3 and 4 were generated.

According to student responses overall, substantial improvements had occurred as a result of their participation in the programme. This is evidenced by the high percentage of positive changes: $89 \%, 83 \%, 78 \%$, $76 \%, 75 \%$ and $75 \%$ of students reported improvements in the areas of "seeing a reason to be at school", "getting on with other students", "the
Table 3 Identified areas of most positive change

\begin{tabular}{lccc}
\hline & $\begin{array}{c}\text { Positive } \\
\text { change }\end{array}$ & No change $\begin{array}{c}\text { Change for the } \\
\text { worse }\end{array}$ \\
\hline $\begin{array}{l}\text { Seeing a reason to be at school } \\
\text { Getting on with other students }\end{array}$ & $89 \%$ & $11 \%$ & 0 \\
$\begin{array}{l}\text { The marks I'm getting for my } \\
\text { work }\end{array}$ & $78 \%$ & $13 \%$ & $4 \%$ \\
$\begin{array}{l}\text { The amount of work I'm doing } \\
\text { at school }\end{array}$ & $76 \%$ & $15 \%$ & $9 \%$ \\
$\begin{array}{l}\text { The amount of classes I go to } \\
\text { The amount of trouble I get }\end{array}$ & $75 \%$ & $16 \%$ & $9 \%$ \\
into at school & $75 \%$ & $6 \%$ & $19 \%$ \\
\hline
\end{tabular}

Table 4 Identified areas of least positive change

\begin{tabular}{lccc}
\hline & $\begin{array}{c}\text { Positive } \\
\text { change }\end{array}$ & No change & $\begin{array}{c}\text { Change for the } \\
\text { worse }\end{array}$ \\
\hline Getting hassled by teachers & $53 \%$ & $19 \%$ & $28 \%$ \\
Level of boredom at school & $46 \%$ & $15 \%$ & $39 \%$ \\
$\begin{array}{l}\text { The amount of homework } \\
\text { I am doing }\end{array}$ & $45 \%$ & $16 \%$ & $39 \%$ \\
\hline
\end{tabular}

marks I'm getting for my work", "the amount of work I'm doing at school", "the amount of classes I go to" and "the amount of trouble I get into at school" respectively. Even areas where positive change is less marked - "getting hassled by teachers", "level of boredom at school" and "the amount of homework I am doing" - positive responses are 
higher than the negative ones $(53 \%, 46 \%$ and $45 \%$ respectively, as compared to $28 \%, 39 \%$ and $39 \%$ ).

\section{Part II: What was most important about your tutor?}

At the debriefing which followed each course, students were asked to sort a set of eight cards in order to rank the characteristics they considered to be most important for a CRASH course tutor (youthworker). Most groups sorted the extremities of the scale first, deciding what was most important and then least important before sorting out the middle cards. The following chart (Table 5) is representative of all groups' responses. ${ }^{8}$

Table 5 Ranking of (major) tutor characteristics in order of importance

\begin{tabular}{|c|c|c|}
\hline least important & $\begin{array}{c}\text { What was most } \\
\text { important about } \\
\text { our tutor }\end{array}$ & most important \\
\hline & They listened to us & 000000000000000000000000 \\
\hline & $\begin{array}{l}\text { They understood } \\
\text { where we were coming } \\
\text { from }\end{array}$ & 00000000000000000 \\
\hline 00 & They were encouraging & 000000000000000 \\
\hline 00 & $\begin{array}{c}\text { They didn't act like a } \\
\text { teacher }\end{array}$ & 0000000000 \\
\hline & $\begin{array}{l}\text { They were reliable to } \\
\text { do what they said }\end{array}$ & 000000000 \\
\hline 000000 & $\begin{array}{c}\text { They were on the same } \\
\text { level as us }\end{array}$ & 0000000 \\
\hline 000000000000000000 & $\begin{array}{l}\text { They were } \\
\text { Maori/Samoan }\end{array}$ & \\
\hline 000000000000000000000000 & $\begin{array}{c}\text { They were close to our } \\
\text { own age }\end{array}$ & \\
\hline
\end{tabular}

One of the intentions of the programme was to involve local (and either untrained or informally trained) youthworkers as CRASH tutors, that is, people with street-knowledge and skills and points of commonality, in preference to professionally-trained people. The researchers had a sense that the most important element for success would be that the youthworkers would have similar experiences, worldviews and be ethnically similar (if not the same) as the "at risk" students and would therefore have excellent foundations for building relationships within CRASH.

The above results seem to indicate (overwhelmingly) that rather than the areas of commonality of ethnicity and age (identifying features) being most important, it was a sense of being heard ("they listened to us"), that tutors "understood where we are coming from", "were encouraging", "didn't act like teachers" and could be relied on to do what they said they would (inward qualities), that they identified as most important.

\section{Part III: The interviews}

Interviews with students took place either as part of the debriefing process at the end of a course or at a convenient time with students doing the contract programme. The results from the questionnaire indicated that the students genuinely felt that they had made large strides after their participation in CRASH, and also indicated in which areas. Similarly, the focus group research gave a student perspective of what the qualities of an ideal tutor should be. The interviews provided useful information which both complemented the questionnaire and the focus group research and also provided further information and insights.

Question $i$. Did you feel that the project made any difference for you?

The students who had participated in the project were very positive about the difference it had made for them. They identified changes in themselves in terms of both attitude and behaviour.

a. Behaviour

Most students reported that their behaviour had changed for the better as a result of participation in the CRASH programme.

I used to take some [drugs] nearly every day at school, but since I've been with [the CRASH course] I've been able to stop. It's helped me go to classes more, 'cause usually I'd wag if I'd taken some, so I wouldn't get caught stoned.

It had helped me to speak up [in the group situation], to become more confident. 
It helped us to see the [school] subjects we needed to do and where to go in the community [for help].

\section{b. Motivation}

Many students identified the main benefit from CRASH as being motivational, particularly in helping them to find reasons to make more of an effort at school.

It keeps you out of trouble, sometimes like at school, on Mondays when you come to school you've got something to look forward to.

It helps you stay out of trouble ... because we want to be in the auction and go on the rafting trip and stuff.

I used to base my week around the course, just hold on [and avoid getting into trouble] so I can get on it.

Like last term, I wasn't doing like no work at all, and now I like working 'cause I like coming to CRASH.

One specific area that acted as a motivation for several students was the chance to have "time out" from the school routine:

Before I was getting good [marks] for my work but bad for my behaviour and now I've got 4's for both of them [a good mark]. I think it was the course because you get a break from teachers and you don't get annoyed with them as much.

It was clear that as a result of participating in the CRASH course, a number of students felt more in tune with the goals of the school or at least were trying to achieve some measure of success, however small. There was a sense that CRASH had been positive in terms of helping to develop better attitudes, motivation and self-esteem for some of the students. It is important, however, to be aware that this was the perception of the students immediately after having participated in the CRASH programme. Whether these changes could be sustained in a school culture where, for many years, these students had been deemed failures and troublemakers, is probably the most important ongoing issue.

\section{Question ii. What did you think of your tutor?}

For the most part, the students were very positive about the tutors. The tutors usually took their groups outside of the school and developed activities that were intended to break down the formal boundaries that often exist in school (which are, of course, justified because of the need to cover specified curriculum material within limited periods of time, amongst other things). Also, the "at risk" students, who are often in trouble at school and hate being there, will almost inevitably make comparisons between the teachers and the tutors. Indeed, the tutors were often compared very favourably against the teachers.

a. Being listened to, understood and given credibility

"Feeling listened to" emerged as the most important quality students identified in the survey. The interviews showed that being listened to meant that both the individuals and group as a whole were not only listened to, but that they were also "heard", that is, the tutors listened to their suggestions, gave them realistic feedback and often acted on these. Not all suggestions were accepted (which would have been seen as weak and trying to please) but decisions were made after discussion, coming to a conclusion that was well-considered and fair.

[I liked] the way he let the group decide on everything we did, not just like he took charge and we did what he wanted.

Being heard also meant discussing concerns and problems in a non-judgemental, supportive and problem-solving fashion:

Like asking us how we are at school, and just talking it over ... .

She sits there and waits till we've finished, and if she thinks that we've finished she'll just wait for a couple of seconds to make sure that we are finished and then she'll talk to us. Mainly with teachers you can't finish what you're saying.

She's like a counsellor sort of. She asks us do we have anything else that we would like to talk about, and we can talk to her because so many teachers they just think the worst of us straight away. They don't listen to what we've got to say and she does.

\section{b. Confidentiality}

Central to this perceived counselling role is confidentiality and being able to trust.

I know that everything we say to her is confidential and she's not going to tell anyone...

... if we are in trouble, she's just there to help us get out of what we are doing. Like she won't tell our parents or our teacher or nothing, she'll just try and help us to try and stop.

... she's not going to tell anyone, because then you won't be honest 
with her, because if you think she's going to [tell others] you'll get into trouble.

For one group the issue came up in a discussion of their group process, and there was a sense that in this particular setting it was not safe to be so open about confidential matters:

When helping us she shouldn't ask us in groups because some people don't like answering.

Because they're from school you don't know who will blurt things out when you go back.

Like it wouldn't have been bad if we were all friends [the students on the course].

In contrast, a group of students who were friends and who were doing the contracts (individual interview sessions) mentioned that they would prefer some contract sessions together as a group so that they could share their struggles with each other and get support from each other between meetings.

c. How do you know if someone understands where you are coming from?

Also important for the students was the fact that the tutors "spoke the same language" and all this entails, that is, being familiar with the values and icons of the group and having had similar experiences. The following quotations illustrate this. Several of the groups felt strongly about the importance of this concept, but seemed to struggle to put what they felt into words.

Like it is the way she talks to you.

He uses the words we understand.

He just knows how things are for us.

You can't put it into words, you just know.

When asked to describe their relationship with their tutor, one group likened it to a relationship with a respected older brother or sister, someone who was part of their own world and that of the adult world, and perhaps was able to act as a link between the two.

He was like a teacher but he wasn't like a teacher.

He would listen like to what we want to do and stuff like that, he was like a student like us, but like a teacher sometimes.
More friendly than a teacher, and encouraging.

A question asked was: "Would it be just the same if we had some teachers coming in to run these courses?" Here are two responses:

No, it's better with the people we just get to know [for the first time] instead of having a teacher because a teacher thinks, Oh we're not going to listen to them because they're naughty and they make up lots of lies and you know, we' re going to get into trouble and stuff. But she [the tutor] doesn't.

Mainly with other teachers, once you say something that you've done [that's against school rules or illegal] they blow you up and you can't finish what you're saying.

d. Criticisms of some tutors

Although the students were themselves sometimes inconsistent, late or unreliable, they did not tolerate this in their tutor. As one student stated, "Some were disorganised or didn't appear to know what they were doing."

Another negative reaction came from a sense that some tutors had ulterior motives. For example, one student felt imposed upon by a tutor who played Christian music while her group was travelling in her van. Another similar concern was that some tutors appeared to be empowering the group by seeming to involve them in the planning and decision-making while in fact making the decisions themselves and ignoring the suggestions of the group. This made the students feel patronised.

\section{Question iii. How could the programme have run better?}

The interviews generally finished with this question and the inevitable response seemed to be that it would be better if the course was longer and there was more money in the budget for each group (each tutor had a $\$ 100$ budget for activities) so that they could do more activities. Responses included:

Should be a whole day.

It needs to be more like 8-10 sessions [instead of 6]

The whole year man.

More money, way more money and go-carting. 
During the discussions, the initial focus of the boys' groups was generally on their perceptions of the activities run during the course, and particularly those activities that were high interest. So if they went to the movies, or went on an outdoors activity, this was immediately mentioned and presented as if it was a normal part of the course rather than a highlight. Feedback from teachers suggested that students from the courses also presented them in this way back to other students in their classes, which helped to maintain the perception for some that the courses were a "reward for bad behaviour".

During the interviews with the girls' groups, discussion usually moved off activities and focused on the interaction within the group (what they talked about and what their tutor was like). Mid-way through the project, one of the (male) tutors took his group of boys on several high-cost activities (such as indoor go-kart racing). This immediately set a benchmark for the rest of the project and all of the groups pestered their tutors to go there as well. Interestingly, the group that did go initially did not think much of either their course or their tutor. It appeared that having raised the expectations of high interest activities, the tutor had created a dynamic within the group whereby he had to raise the stakes to keep the interest of the group. So by contrast, the other activities this person ran were considered "boring". There also appeared to be a low level of interaction within the group.

Some groups of students were very clear about what they had discussed, and were able to comment about whether it had been helpful. Others were able to talk about the activities but drew a blank when asked what they had talked about. It appeared that some tutors with either fewer skills, or less confidence, tended to rely on activities rather than interaction to make their course work. Although on one level the students seemed to appreciate the activities, they also tended to be more critical of tutors who operated only in this way.

Some of the most successful courses were run by tutors who used a range of low-key activities, such as a walk on the beach and a cup of coffee at their house (girls' group), or regular visits down to the gym (where one tutor worked) for basketball. All of the students preferred to go off the school campus for their sessions. A number expressed their appreciation of the extent to which their tutor allowed them to connect with their own lives, for example, going around to their own homes for a meal or coffee. Some tutors had the ability to create a group dynamic in which their students were invited to participate in an aspect of their world as fellow adults. This seemed to be particularly appreciated by the girls and it perhaps contrasted with roles they were able to play at home and at school.

\section{Question iv. How did the teachers react to your participation in CRASH?}

Although it was not the intention of the project to undermine or attack the teachers or the school, these students had been identified by the school as problematic, "at risk". For the students, probably at least partially empowered by their experiences in the CRASH programme, it was clearly important to articulate their point of view about the school, to provide an alternative narrative, "their own truth".

\section{a. Not being heard}

Students felt that teachers were not prepared to listen to them properly and did not understand where they were coming from. The students were gaining confidence through the course and were prepared to make changes or had already done so, but there was a sense that they were on different wavelengths from the teachers, who often failed to recognise changes in the students' attitudes and behaviours because they were partial and developing rather than miraculous. ${ }^{9}$

\section{b. Being typecast}

A second perception was of being typecast by teachers as the "naughty kids". On several occasions students identified the difficulty they experienced in breaking out of this image.

Once you've been in trouble, it's like they always look at you that way. It's a box that you're in.

Like the teachers hear that someone is being naughty in the class and straight away they think it's you. They think that straight away that you're a trouble-maker.

c. Lack of recognition of efforts and changes

Some students felt unable to break away from the labels they had acquired through previous misbehaviour. While they had regularly articulated goals during a contract session (such as "I will sit separately from my friend so they don't distract me"), they perceived that their effort had not been acknowledged by their teacher, ${ }^{10}$ who had perhaps reacted to their infringement in another area instead (such as incorrect uniform). There was a sense that if they tried to change and were not acknowledged, there was little point in the whole exercise. 


\section{Conclusion}

The CRASH project, in involving youthworkers from the community, sought to provide opportunities for "at risk" youth who had experienced a breakdown in one or more of the four social environments in which they lived. The youthworkers concluded that one goal for their intervention was to become alternative reference points within the adult world for students who have experienced a failure or collapse of other reference points.

The CRASH programme appears to have been reasonably successful. However, it was only an experimental and formative initiative, a mere beginning. What is now needed is the development of a programme which not only builds on the lessons to be learned from the CRASH programme but also provides effective mechanisms for students to avoid becoming "at risk" or casualties of an education system that, in effect, contributes to their marginalisation.

\section{Notes}

1. This disparity may be accounted for, at least in part, by the different criteria used to define and measure "risk". For example, Fergusson, Horwood and Lynskey (1993) include criminal offending within their definition, whereas Australian studies, such as Batten and Russell (1995), have focussed on truancy or early withdrawal from school.

2. The following contributors to this project are acknowledged with gratitude: the students, the teaching staff of the case study school, and the youthworkers and their organisations, the Ministries of Education and Youth Affairs, and the Crime Prevention Unit.

3. As with most research, there are areas that present problems and which are open to interpretation. For example, what does "at risk" mean? How do you measure success? Does it mean an improvement in general behaviour, or in attendance, or in academic success? It is always important to consider the implications of such questions, and assumptions about them.

4. When the profile was used for the 3rd form intake in the following year, it was decided that focus-groups, rather than form teachers, could make better judgements, because they had more contact time with the students.

5. By the end of the first year, 28 of the original 79 had left the school. Others were added to the programme throughout the year by the guidance consellor, in consultation with the school deans. An "at risk" population of 24 percent is very high. By the end of 1996, this had risen to 25 percent.
6. These are a mixture of those moved away, moved onto other programmes (e.g., TOPs), indefinitely suspended, or moved into residential rehabilitation programmes.

7. The process of profiling a student was not an exact one, as was revealed when two teachers each completed a profile for the same group of students independently. A comparison of their assessments revealed a 50 percent difference in the student behaviours they ticked, with the newer teacher identifying far fewer behaviours. This suggests that different levels of knowledge or awareness of students' circumstances exist between teachers. It also underlines the importance of having the assessments of classroom teachers checked by guidance counsellor and deans.

8. The table illustrates the number of times a statement appeared in the top three student choices (most important), and how many times in the bottom three choices (least important).

9. This was sometimes due to the lack of effective communication between the project personnel and the teachers. In 1998 the principal researcher was asked back to the school to give teachers a clearer picture of the processes that occur for "at risk" students.

10. The way contracts were structured meant that teachers were usually unaware of the goals students had set until the end of the week, when teachers were asked to comment on them.

\section{References}

Batten, M. \& Russell, J. (1995). Students at risk: A review of Australian literature 1980-1994. Research Monograph \#46. Melbourne: Australian Council for Educational Research.

Clark, E., Smith, L., \& Pomare, M. (1996). Alternative education provision. Adiscussion paper commissioned by Te Puni Kokiri. Wellington: Te Puni Kokiri/Ministry of Maori Development.

Denny, G. et al. (1993). Indicative survey of at risk students in NZ secondary schools. Porirua: Porirua College.

Elliott, J. (1991). Action research for educational change. Buckingham: Open University Press.

Fergusson, D. M., Horwood, L. J., \& Lynskey, M. T. (1993). Ethnicity, social background and young offending: A fourteen year longitudinal study. Australian and NZ Journal of Criminology, 26, 155170.

Fergusson D. M., Horwood, L. J. \& Lynskey, M. T. (1994). The childhoods of multiple problem adolescents: A fifteen year 
longitudinal study. The Journal of Child Psychology \& Psychiatry and Allied Disciplines, 35(6), 1123-1140.

Lauder, H., Hughes, D., Waslander, S., Thrupp, M., McGlinn, J., Newton, S., \& Dupuis, A. (1994). The creation of market competition for education in New Zealand: An empirical analysis of a New Zealand secondary school market, 1990-1993 (The Smithfield Project) Phase One: First report to the Ministry of Education. Wellington: Ministry of Education.

Lovell, R., \& Norris, M. (1990). One in four: Offending from age ten to twenty-four in a cohort of New Zealand males, study of social adjustment. Research Report No. 8. Wellington: Department of Social Welfare.

Martin, L. (1998). Getting heard - A case study of community involvement with "at risk" secondary school students. Unpublished Master of Education thesis, Victoria University of Wellington.

Nash, R., \& Harker, R. (1994). Progress at school: Stage one final report. Palmerston North:Educational Research and Development Centre, Massey University.

Peters, M., \& Marshall, J. (1989). Research into the retention of Maori students in secondary schools in Tai Tokerau. Wellington: Ministry of Education.

\section{The authors}

Lloyd Martin is currently completing an MEd degree through Victoria University of Wellington. From a background as a teacher and youthworker in the Porirua community for the past 18 years, he now coordinates a national training programme in youthwork.

Keith Sullivan is Director of Postgraduate Studies and a Senior Lecturer in the School of Education at Victoria University of Wellington. His research interests are in New Zealand and comparative education policy, multiethnic education, classroom behaviour, anti-bullying initiatives, and teachers' issues - particularly in relation to ideology and professionalism.

Marcia Norton is Professor of Educational Administration at the State University of New York, New Palz, NY, and a Visiting Research Fellow in the School of Education at Victoria University of Wellington. Her research interests include "at-risk" students, school climate and culture, case study development, non-verbal communication, and teacher and principal training and evaluation. 